\title{
Body Weights of Adult and Juvenile Northern Pocket Gophers, Thomomys talpoides, in Central Alberta Alfalfa Fields
}

\author{
Gilbert PROUlX
}

Alpha Wildlife Research \& Management Ltd., 229 Lilac Terrace, Sherwood Park, Alberta T8H 1W3 Canada

Proulx, Gilbert. 2005. Body weights of adult and juvenile Northern Pocket Gophers, Thomomys talpoides, in central Alberta alfalfa fields. Canadian Field-Naturalist 119(4): 551-559.

In an effort to recognize adults from juveniles in late summer and early fall, carcasses of Northern Pocket Gophers (Thomomys talpoides) captured from April to October 1994 in a pure alfalfa (Medicago spp.) field in Camrose and a mixed alfalfa-orchard grass (Dactylis glomerata)-dandelion (Taraxacum spp.) field in Lacombe, in central Alberta were analyzed. Mean weights of adult males and females were significantly $(P<0.05)$ larger than those of juveniles with near-adult body sizes in late summer and early fall. On the basis of the limits of $95 \%$ confidence intervals for individual values in Camrose and Lacombe, live-captured males weighing $<130 \mathrm{~g}$ could be classified as juveniles; those that are $>180 \mathrm{~g}$ would be adults. Males weighing between $130 \mathrm{and}$ $180 \mathrm{~g}$ could be either juveniles or adults. Live-captured females weighing $<110 \mathrm{~g}$ would likely be juveniles. With larger animals, the pubic symphysis should be used to distinguish young females from adults. Given the variability of body weight in Northern Pocket Gophers, it is suggested that criteria for aging based on weight be derived for local populations in specific habitat types. On average, Northern Pocket Gopher males and females from Camrose were significantly $(P<0.05)$ heavier than those of Lacombe. Animals from both fields were, on average, heavier than those previously studied in natural-vegetation communities. Differences in the food nutritional quality may explain the observed variation in body weights among populations.

Key Words: Northern Pocket Gopher, Thomomys talpoides, Alfalfa, Medicago sp., body weight, Alberta.

In ecological studies, being able to recognize adults from juveniles in late summer and early fall without killing animals is useful to estimate summer mortality rates and population changes in response to environmental fluctuations (Caughley 1977), and conduct behavioral and physiological investigations (Miller 1952). Northern Pocket Gopher (Thomomys talpoides) adults and juveniles are difficult to tell apart in late summer and early fall on the basis of weight. In British Columbia orchard-old field habitats, from July to September, Sullivan et al. (2001) used three age classes of Northern Pocket Gophers based on body weight: juveniles (young of the year, which do not breed until the next year) $<49 \mathrm{~g}$; subadults (individuals of which 50\% are mature in the upper weight class) $49-60 \mathrm{~g}$; and adults ( $\geq 50 \%$ of individuals sexually mature in the lowest weight class) $\geq 61 \mathrm{~g}$. However, previous studies on the body size of Thomomys talpoides (Smith 1940; Hansen 1960; Hansen and Bear 1964; Tryon and Cunningham 1968; Hansen and Reid 1973) and Thomomys bottae, Valley Pocket Gopher, (Howard and Childs 1959; Daly and Patton 1986; Patton and Brylski 1987) showed that animal weights varied among pocket gopher populations due to habitat types, altitude, latitude, and seasons (Hansen and Reid 1973). Patton and Brylski (1987) found that growth rates and body sizes of pocket gophers inhabiting alfalfa monocultures were greater than those of pocket gophers inhabiting natural-vegetation communities. Then, one may wonder about the usefulness of aging criteria based on weight developed in different regions and habitats to study Northern Pocket Gopher populations in alfalfa (Medicago spp.) fields of central Alberta.
According to Reid (1973), young-of-the-year Northern Pocket Gophers would attain near-adult body weight approximately 180 days after birth. That is to say that, in Alberta alfalfa fields where young are born in April-May (Proulx 2002), they would be similar in body size to adults during August-October. However, the growth rate of juvenile pocket gophers may be highly variable from one population to another (Daly and Patton 1986), and Reid's (1973) estimate may not be applicable to central Alberta populations.

Few complete data have been published on body weights of Northern Pocket Gopher populations. Although the Northern Pocket Gopher is common in western Canada (Proulx 2004), little is known about body weights of age and sex classes from different habitats. Within the context of a multi-year ecological study of Northern Pocket Gophers in Alberta alfalfa fields, I collected carcasses to compare body weights of adults and juveniles during summer and early fall in order to determine weight classes that could be used to age animals in live-capture programs. I also wanted to compare the mean weights of adults from central Alberta alfalfa fields to those reported in the scientific literature for other regions and habitat types. I hypothesized that in late summer-early fall: (1) on average, adults would be heavier than juveniles; (2) individual body weights of adults and juveniles would overlap; (3) body weight categories may be established to differentiate some juveniles from adults; and (4) mean body weights of adults inhabiting alfalfa fields would be larger than those of adults from natural-vegetation communities. 


\section{Methods}

The study was carried out in two alfalfa fields of central Alberta, in the communities of Camrose and Lacombe. The Camrose field was a 3-year-old pure alfalfa stand with a high forage yield and excellent second cutting (Alberta Agriculture 1992*). The Lacombe field was approximately 5 years old, and corresponded to a mixture of alfalfa with orchard grass (Dactylis glomerata) and abundant dandelion (Taraxacum spp.). Alfalfa was cut once and thereafter the field was used as pasture. Spring adult populations were estimated at 22.4 animals/ha in Camrose (Proulx 1997), and 23.5/ha in Lacombe (Proulx 1995*). The ratio male:female was 0.7:1 in Camrose, and 0.75:1 in Lacombe. Mean litter size was significantly larger in Camrose $(\bar{x}=6.4$; standard deviation $=1.4)$ than in Lacombe $(5.1 \pm 1.1)$ (Proulx 2002)

In 1994, kill-trapping was conducted from 18 April to 27 October. Trapping methodology was described by Proulx (1997). Animals were individually marked in the field, and frozen. The weight, sex and age were determined in the laboratory. In central Alberta, females produce only one litter (Proulx 2002). The size of the reproductive organs was used to distinguish young-of-the-year from adults. Young males have smaller testes, and young females have smaller ovaries and narrower uterine horns than adults (Hansen 1960; Hansen and Reid 1973). As precocial breeding is not known to occur in Alberta populations (Proulx 2002; Proulx and Cole 2002), the pubic symphysis was also used to distinguish young females from adults; in adult females the bones are resorbed, leaving a pubic gap (Hisaw 1924; Hansen 1960).

An analysis of variance followed by the Tukey test was used to compare mean weights between Camrose and Lacombe population samples (Zar 1999). Student t-tests were used to compare mean body weights of Northern Pocket Gophers of Camrose and Lacombe populations to those of populations reported in the scientific literature. Probability values $P \leq 0.05$ were considered statistically significant.

\section{Results \\ Males}

Mean weights of Camrose adult males differed significantly $\left(\mathrm{F}_{2,63}=5.9, P<0.005\right)$ among samples collected from 18 April to 31 May. Animals captured in late May were significantly $(P<0.005)$ lighter than those collected earlier in the year (Table 1). In Lacombe, mean weights of adult males were similar $\left(\mathrm{F}_{3,86}=1.7\right.$, $P>0.05)$ among samples collected from 18 April to 31 May (Table 1).

Mean weights of juvenile males differed significantly among samples in Camrose $\left(\mathrm{F}_{4,74}=21.7, P<0.005\right)$ and Lacombe $\left(\mathrm{F}_{4,67}=11.3, P<0.005\right)$ (Table 1). Juveniles captured in September-October were the heaviest; they were similar in size $(P>0.05)$ to those captured in August-September (Table 1).
Mean weights of adults and juveniles differed significantly in Camrose $\left(\mathrm{F}_{4,74}=21.7, P<0.005\right)$ and Lacombe $\left(\mathrm{F}_{5,156}=80.2, P<0.005\right)$. In both study areas, the mean adult weight was larger $(P<0.001)$ than that of each juvenile sample collected from June to October (Table 1). In Camrose, the limits of $95 \%$ confidence intervals for individual values were 142$230 \mathrm{~g}$ for adults, and 108-172 $\mathrm{g}$ for September-October juveniles. In late summer-early fall, although males were, on average, heavier than juveniles, there was a marked overlap between age class weights. Then, on the basis of weight alone, live-captured animals weighing between 142 and $172 \mathrm{~g}$ could be classified as either adults or juveniles. Those weighing $<142 \mathrm{~g}$ could be juveniles while those $>172 \mathrm{~g}$ could be adults. In Lacombe, the limits of $95 \%$ confidence intervals for individual values were 136-213 $\mathrm{g}$ for adults, and 106-174 g for September-October juveniles. Live-captured animals weighing between 136 and $174 \mathrm{~g}$ could then be classified as either adults or juveniles. Those weighing $<136 \mathrm{~g}$ could be juveniles while those $>174 \mathrm{~g}$ could be adults.

\section{Females}

In Camrose, mean weights of adult females were similar $\left(\mathrm{F}_{3,113}=1.0, P>0.05\right)$ among samples collected from 18 April to 27 June (Table 1). In Lacombe, mean weights of adult females differed significantly $\left(\mathrm{F}_{4,107}=3.0, P<0.05\right)$ among samples collected from 18 April to 27 October. Animals captured in late May and in August-October were the only samples to differ significantly $(P<0.005)$ from each other (Table 1$)$.

Mean weights of juvenile females differed significantly among samples in Camrose $\left(\mathrm{F}_{2,38}=20.3\right.$, $P<0.005)$ and Lacombe $\left(\mathrm{F}_{3,34}=11.8, P<0.005\right)$ (Table 1). In Camrose, juveniles captured in AugustSeptember and in July were of similar $(P>0.05)$ size, but were larger $(P<0.05)$ than those of June (Table 1). In Lacombe, juveniles captured from August to October were of similar $(P>0.05)$ size, but were larger $(P<0.05)$ than those of July (Table 1$)$.

Mean weights of adults and juveniles differed significantly in Camrose $\left(\mathrm{F}_{3,154}=120.5, P<0.005\right)$ and in Lacombe $\left(\mathrm{F}_{4,145}=27.5, P<0.005\right)$. In both study areas, the mean weight of adults was larger $(P<0.001)$ than that of each juvenile sample collected from June to September (Table 1). In Camrose, the limits of $95 \%$ confidence intervals for individual values were 126$195 \mathrm{~g}$ for adults, and 89-163 g for August-September juveniles. Although female adults were, on average, heavier than juveniles, there was a marked overlap between age class weights. Therefore, on the basis of weight alone, live-captured animals weighing between 126 and $163 \mathrm{~g}$ could be either adults or juveniles. Females weighing $<126 \mathrm{~g}$ could be juveniles while those $>163 \mathrm{~g}$ could be adults. In Lacombe, the limits of $95 \%$ confidence intervals for individual values were 113-175 $\mathrm{g}$ for adults and 101-180 $\mathrm{g}$ for September- 


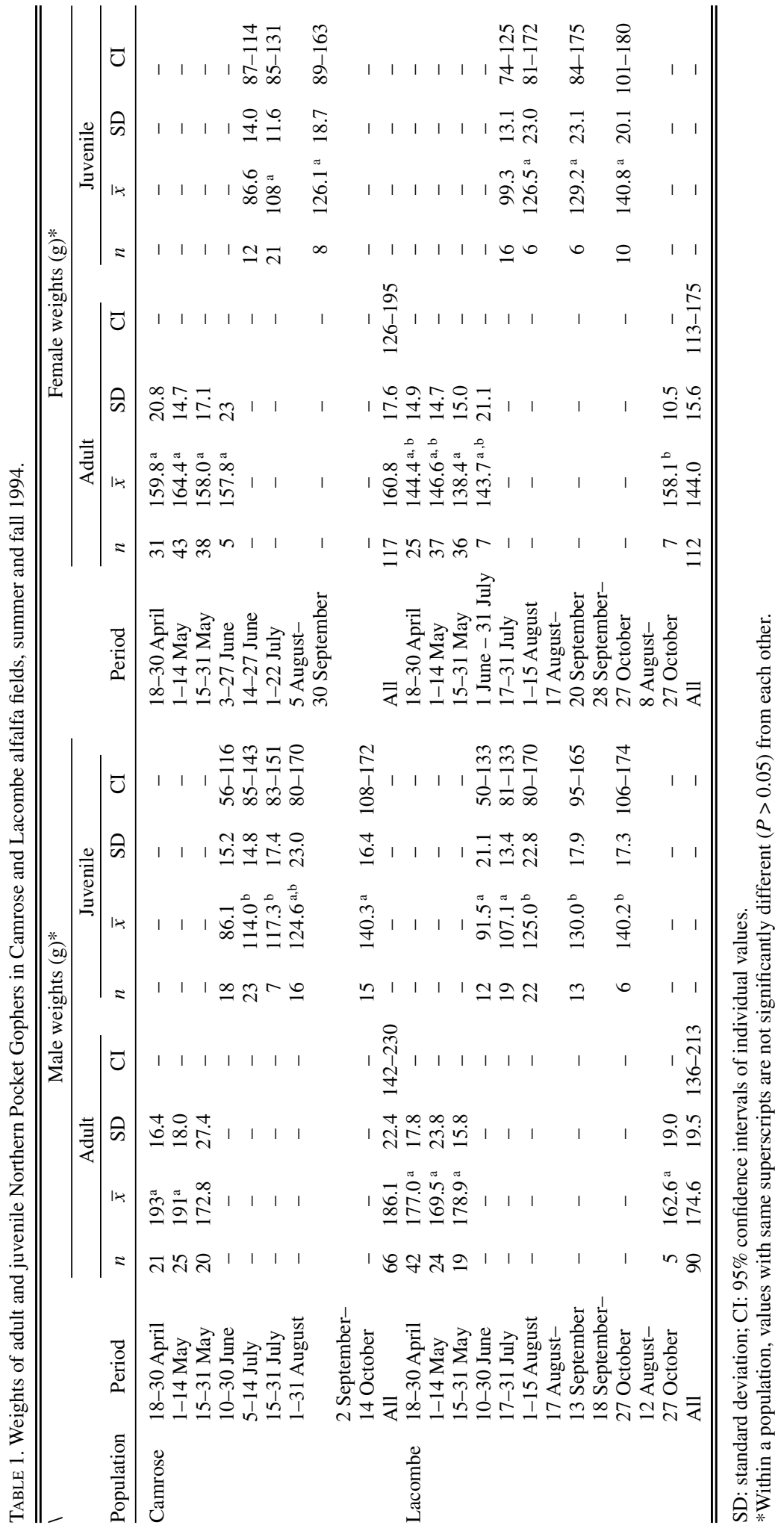


October juveniles. Live-captured animals weighing $<113 \mathrm{~g}$ could be classified as juveniles; those weighing $\geq 113 \mathrm{~g}$ could be either adults or juveniles.

\section{Comparison between adult populations}

Mean weights of Camrose and Lacombe adults differed significantly $\left(\mathrm{F}_{3,381}=86.7, P<0.005\right)$. On average, Camrose males and females were heavier $(P<0.005)$ than those of Lacombe.

On average, adult males from Camrose and Lacombe were significantly $(P<0.05)$ heavier than adult males from other alfalfa fields or habitat types (Table 2). On average, adult females from Camrose were also significantly $(P<0.05)$ heavier than females from other habitat types and regions. The mean weight of Lacombe adult females was, however, similar $(P>0.05)$ to those of females inhabiting alfalfa fields in Saskatchewan and Colorado (May sample), and unspecified agricultural lands in central Alberta (Table 2).

The Camrose and Lacombe adult males and females were at least $25 \%$ heavier than males and females found in habitats other than alfalfa fields. They were more than twice as heavy as Northern Pocket Gophers captured in British Columbia (Table 2).

\section{Discussion}

In this study, the hypothesis that adults would be, on average, heavier than juveniles in late summer-early fall was validated. Adult females grow until 2 years old, and males continue to grow throughout their lifetime (Tryon 1947; Miller 1952; Howard and Childs 1959; Daly and Patton 1986). Even though young-of-the-year appeared as large as adults, they were approximately 6-7 months old in the fall, and their growth was not completed (Tryon 1947). On the other hand, body sizes of juveniles and adults vary considerably within the same habitat due to differential individual growth rates from a same litter or population (Tryon 1947; Daly and Patton 1986), age of the individuals (i.e., older juvenile vs. younger adult) (Hansen and Bear 1964), and time of year (Miller 1952; this study). All this may explain the marked overlap observed within juvenile populations from August to October, and between juveniles and adults, as reported in previous studies (Tryon 1947; Miller 1952; Hansen and Bear 1964).

This study, and previous work (Tryon 1947; Hansen and Reid 1973; Hansen and Bear 1964), showed that mean body weights of age and sex classes varied considerably within and between study areas. Therefore, it is unlikely that reliable body weight categories may be established to differentiate juveniles from adults. At best, confidence intervals for individual values may be cautiously used to recognize lighter juveniles and heavier adults. Using confidence intervals of individual values for juvenile and adult males in Camrose and Lacombe, I propose that, in late summer-early fall, live-captured animals weighing $<130 \mathrm{~g}$ would likely be juveniles. Individuals weighing $>180 \mathrm{~g}$ may be adults. Animals weighing between 130 and $180 \mathrm{~g}$ might be either juveniles or adults. In the case of females, animals weighing $<110 \mathrm{~g}$ would likely be juveniles. Larger animals should be classified on the basis of the presence of an open pelvic girdle, i.e., the pubic bones are widely separated due to the permanent resorption of the symphysis at first pregnancy (Miller 1952).

Given the variability of body weight in pocket gophers, any criteria for aging based on weight will

TABLE 2. Mean weights of adult Northern Pocket Gophers reported in the scientific literature.

\begin{tabular}{|c|c|c|c|c|c|c|c|c|}
\hline \multirow[b]{3}{*}{ Location } & \multirow[b]{3}{*}{ Habitat types } & \multirow[b]{3}{*}{ Period } & \multicolumn{6}{|c|}{ Adult weights (g) } \\
\hline & & & \multicolumn{3}{|c|}{ Males } & \multicolumn{3}{|c|}{ Females } \\
\hline & & & $n$ & $\bar{x}$ & $\begin{array}{l}\text { Standard } \\
\text { deviation }\end{array}$ & $n$ & $\bar{x}$ & $\begin{array}{l}\text { Standard } \\
\text { deviation }\end{array}$ \\
\hline \multirow[t]{2}{*}{ Alberta } & Unspecified agricultural land near & & & & & & & \\
\hline & Edmonton - MacDonald (1969) & Summer & 43 & 133 & 14 & 37 & 138 & 20 \\
\hline British & Forb-orchard - Sullivan et al. (2001) & Summer 1982 & 28 & 69 & 2 & 23 & 68 & 2 \\
\hline \multirow[t]{3}{*}{ Columbia } & Old field-orchard - Sullivan et al. (2001) & Summer 1983 & 69 & 71 & 2 & 49 & 60 & 1 \\
\hline & Orchard - Sullivan et al. (2001) & Summer 1983 & 22 & 61 & 4 & 58 & 63 & 1 \\
\hline & & Summer 1985 & 22 & 74 & 4 & 59 & 65 & 2 \\
\hline \multirow[t]{9}{*}{ Colorado } & Alfalfa field - Hansen (1960) & April & 86 & 159 & 61 & 49 & 136 & 20 \\
\hline & & May & 58 & 158 & 15 & 36 & 135 & 20 \\
\hline & & June & 18 & 148 & 21 & 25 & 136 & 16 \\
\hline & & August & 9 & 158 & 19 & 22 & 135 & 19 \\
\hline & & September & 9 & 176 & 17 & 12 & 158 & 11 \\
\hline & Alpine tundra - Hansen and Bear (1964) & August & 14 & 114 & 8 & 34 & 106 & 12 \\
\hline & Meadow - Hansen and Bear (1964) & August & 8 & 134 & 18 & 29 & 108 & 12 \\
\hline & Shrub-bunchgrass - Hansen and Bear (1964) & August & 8 & 116 & 12 & 30 & 105 & 12 \\
\hline & Weedy rangeland - Hansen and Ward (1965) & August & 37 & 127 & 13 & 46 & 114 & 14 \\
\hline Saskatchewan & Alfalfa field - Runnells (1988) & $\begin{array}{l}\text { Summers } 1983 \\
\text { and } 1984\end{array}$ & 32 & 158 & 41 & 71 & 141 & 63 \\
\hline Utah & Coniferous forest - Andersen (1978) & June-October & 5 & 104 & 3 & 14 & 91 & 2 \\
\hline
\end{tabular}


have to be derived for local populations in specific habitat types. Body weight confidence intervals determined in this study may be useful to researchers working on Northern Pocket Gophers in central Alberta alfalfa fields. These confidence intervals would not be reliable to age live-captured animals from meadows, old field or orchard populations. Habitat differences in nutritional quality of available food can directly affect the observed variation in body weight among populations of pocket gophers (Smith and Patton 1980; Patton and Brylski 1987). Alfalfa is a superior forage producing more protein per ha than any other crop or grass (Heath et al. 1973). Northern Pocket Gophers inhabiting Camrose and Lacombe alfalfa fields were heavier than animals from other habitat types. A difference in the quality of food available in pure and mixed alfalfa fields may also explain the difference in the mean weights of Northern Pocket Gophers inhabiting Camrose and Lacombe.

\section{Acknowledgments}

I thank Pam Cole, Joel Nicholson, Nicole Proulx, Orest Litwin and Paul King for technical support, and Pauline Feldstein for reviewing an earlier draft. I am especially grateful to referee David Nagorsen for providing an insightful review of an earlier draft of this paper.

Documents Cited (marked * in text)

Alberta Agriculture. 1992. Alberta forage manual. Agdex 120/20-4, Edmonton, Alberta.

Proulx, G. 1995. Development of a northern pocket gopher border control strategy. Alpha Wildlife Research and Management Ltd. report prepared for the Counties' Pocket Gopher Control Program, County of Red Deer, Alberta.

\section{Literature Cited}

Andersen, D. C. 1978. Observations on reproduction, growth, and behavior of the northern pocket gopher (Thomomys talpoides). Journal of Mammalogy 59: 418-422.

Caughley, G. 1977. Analysis of vertebrate populations. John Wiley \& Sons Ltd., New York New York. 234 pages.

Daly, J. C., and J. L. Patton. 1986. Growth, reproduction, and sexual dimorphism in Thomomys bottae pocket gophers. Journal of Mammalogy 67: 256-265.

Hansen, R. M. 1960. Age and reproductive characteristics of mountain pocket gophers in Colorado. Journal of Mammalogy 41: 323-335.

Hansen, R. M., and G. D. Bear. 1964. Comparison of pocket gophers from alpine, sub-alpine, and shrub-grassland habitats. Journal of Mammalogy 45: 638-640.

Hansen, R. M., and V. H. Reid. 1973. Distribution and adaptations of pocket gophers. Pages 1-19 in Pocket gophers and Colorado mountain rangeland. Edited by G. T. Turner, R. M. Hansen, V. H. Reid, H. P. Tietjen, and A. L. Ward. Colorado State University, Fort Collins, Bulletin 554S. 90 pages.

Hansen, R. M., and A. L. Ward. 1965. Some relations of pocket gophers to rangelands on Grand Mesa, Colorado.
Colorado Agricultural Experiment Station, Technical Bulletin 88 .

Heath, M., D. S. Metcalfe, and R. F. Barnes. 1973. Forages. The science of grassland agriculture. Third edition. The Iowa State University Press, Ames, Iowa. 755 pages.

Hisaw, F. L. 1924. The absorption of the pubic symphysis of the pocket gopher, Geomys bursarius (Shaw). American Naturalist 58: 93-96.

Howard, W. E., and H. E. Childs, Jr. 1959. Ecology of pocket gophers with emphasis on Thomomys bottae mewa. Hilgardia 29: 277-358.

MacDonald, S. J. 1969. A taxonomic study of the pocket gophers of Alberta. Mammalia: Geomyidae: Thomomys talpoides (Richardson). M.Sc. thesis, University of Alberta, Edmonton. 70 pages.

Miller, M. A. 1952. Size characteristics of the Sacramento Valley pocket gopher (Thomomys bottae navus Merriam). Journal of Mammalogy 33: 442-456.

Patton, J. L., and P. V. Brylski. 1987. Pocket gophers in alfalfa fields: causes and consequences of habitat-related body size variation. The American Naturalist 130: 493-506.

Proulx, G. 1997. A northern pocket gopher (Thomomys talpoides) border control strategy: promising approach. Crop Protection 16: 279-284.

Proulx, G. 2002. Reproductive characteristics of northern pocket gophers, Thomomys talpoides, in Alberta alfalfa fields. Canadian Field-Naturalist 116: 319-321.

Proulx, G. 2004. Effects of female scents on the trappability of northern pocket gophers (Thomomys talpoides). Crop Protection 23: 1055-1060.

Proulx, G., and P. J. Cole. 2002. Evidence of a second litter in northern pocket gophers, Thomomys talpoides. Canadian Field-Naturalist 116: 322-323.

Reid, V. H. 1973. Population biology of the northern pocket gopher. Pages 21-41 in Pocket gophers and Colorado mountain rangeland. Edited by G. T. Turner, R. M. Hansen, V. H. Reid, H. P. Tietjen, and A. L. Ward. Colorado State University, Fort Collins, Bulletin 554S. 90 pages.

Runnells, J. 1988. Some aspects of population dynamics within a southern Saskatchewan population of northern pocket gophers (Thomomys talpoides). M.Sc. thesis, University of Regina, Saskatchewan. 116 pages.

Smith, C. F. 1940. Weights of pocket gophers. Journal of Mammalogy 21: 220.

Smith, M. F., and J. L. Patton. 1980. Relationships of pocket gophers (Thomomys bottae) of the lower Colorado River. Journal of Mammalogy 61: 733-756.

Sullivan, T. P., D. S. Sullivan, and E. J. Hogue. 2001. Reinvasion dynamics of northern pocket gopher (Thomomys talpoides) populations in removal areas. Crop Protection 20: $189-198$.

Tryon, C. A., Jr. 1947. The biology of the pocket gopher (Thomomys talpoides) in Montana. Montana State College Agricultural Experimental Station, Technical Bulletin 448. 30 pages.

Tryon, C. A., and H. N. Cunningham. 1968. Characteristics of pocket gophers along an altitude transect. Journal of Mammalogy 49: 699-705.

Zar J. H. 1999. Biostatistical analysis. Fourth edition. Prentice-Hall, Inc. Upper Saddle River, New Jersey. 663 pages.

Received 30 November 2004

Accepted 6 October 2005 